NBER WORKING PAPER SERIES

REFORMING BUDGETARY LANGUAGE

David F. Bradford

Working Paper 8500

http://www.nber.org/papers/w8500

\author{
NATIONAL BUREAU OF ECONOMIC RESEARCH \\ 1050 Massachusetts Avenue \\ Cambridge, MA 02138 \\ October 2001
}

This paper is a revised version of one presented at Public Finances and Public Policy in the New Millennium, a conference on the occasion of Richard Musgrave's 90th and CES's $10^{\text {th }}$ Birthdays, University of Munich, January 12-13, 2001, and will appear in a forthcoming festschrift based on the conference. I would like to thank William Gale, Sherry Glied, Deborah Lucas, Joel Slemrod and Daniel Shaviro, as well as participants at the Munich conference, especially Henry Aaron, for helpful comments and conversations. The views expressed herein are those of the author and not necessarily those of the National Bureau of Economic Research.

(C) 2001 by David F. Bradford. All rights reserved. Short sections of text, not to exceed two paragraphs, may be quoted without explicit permission provided that full credit, including $(\mathcal{C}$ notice, is given to the source. 
Reforming Budgetary Language

David F. Bradford

NBER Working Paper No. 8500

October 2001

JEL No. H11, H20, H61

\begin{abstract}
$\underline{\text { ABSTRACT }}$
In the context of several examples of problems associated with present budgetary conventions, I revisit Musgrave's conceptual division of the government's program into Allocation, Distribution and Stabilization Branch subbudgets. I suggest progress towards Musgrave's ideal of a more informative budgetary "language," one less dependent on arbitrary institutional labeling, must be based on the nonarbitrary description of the individual's economic environment, as it is affected by government. As a first approximation, that environment can be summed up in terms of the individual's budget constraint and levels of public goods provided. Simple models suggest that an unambiguous budgetary language may be feasible but there remains much to clarify about both the objectives of the exercise and the specifics of methods to deal with particular problems.
\end{abstract}

David F. Bradford

Woodrow Wilson School

Princeton University

Princeton, NJ 08544

and NBER

bradford@princeton.edu 


\section{Outline}

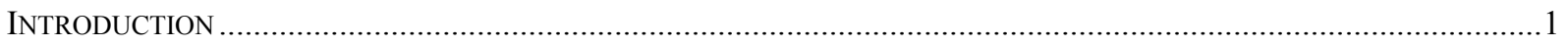

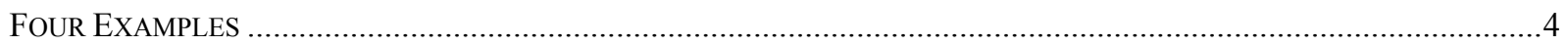

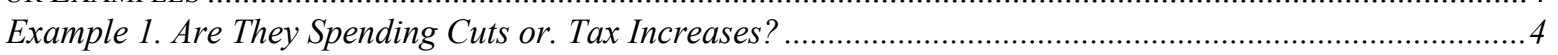

Example 2. A Balanced Budget Policy Change May Be Hard on Future Generations .....................................6

Example 3. Tax Expenditures and Their Opposites (Taxes?) ....................................................................... 7

Example 4. How to Spend (and Tax) Without Spending (or Taxing): Mandates........................................... 8

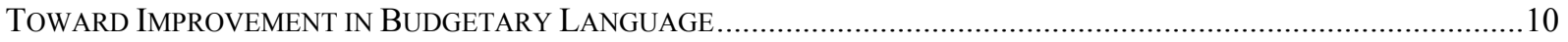

BUdGETARY LANGUAGE IN SOME SIMPLE MODEL ECONOMIES ..................................................................... 12

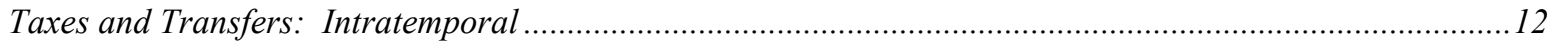

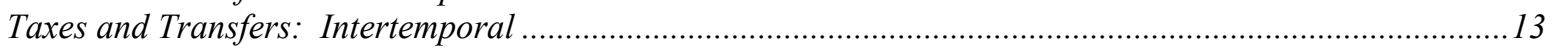

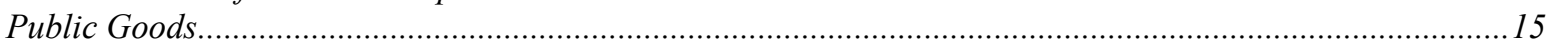

Distorting Commodity Taxes and Subsidies .................................................................................... 17

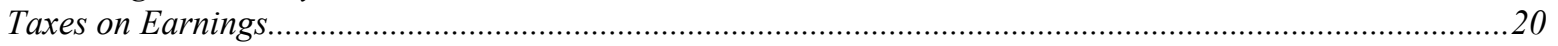

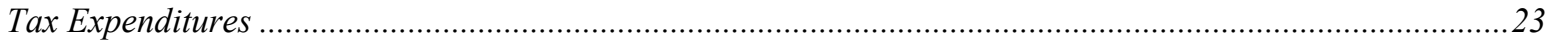

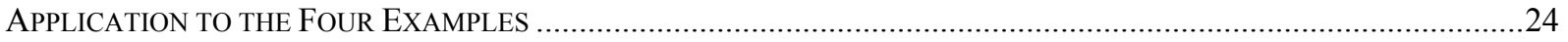

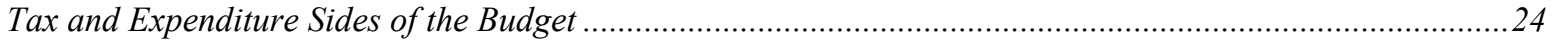

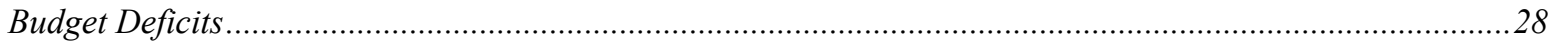

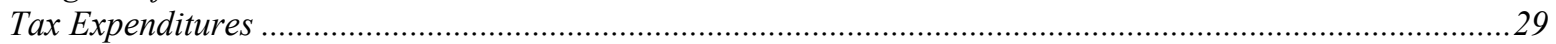

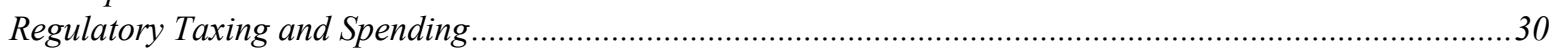

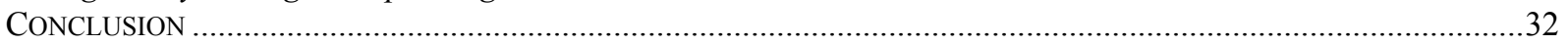

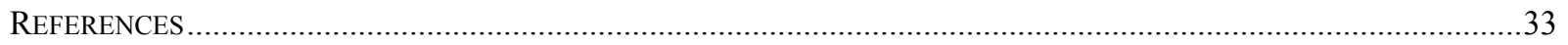




\title{
Reforming Budgetary Language
}

\author{
David F. Bradford
}

The administrative case for budget consolidation is self-evident... But this consolidation is a matter of administrative expediency only; we must not lose sight of the basic principle that the consolidated budget has no rationale on its own...

Consolidation, to be sure, presents no dangers in our imaginary model of efficient budgeting. ... But in the real world the matter is regarded differently; there the tendency is to view the budget in consolidated terms from the outset, and thus to confuse the underlying issues in the planning stage.

Richard A. Musgrave, The Theory of Public Finance, 1959, pp. 37-38

(emphasis in the original).

\section{$\underline{\text { INTRODUCTION }}$}

I was introduced to Richard Musgrave's magisterial treatise as a student in Kenneth Arrow's public finance course at Stanford in the early 60's. Musgrave's application of relatively simple but rigorous economic theory to a wide range of important problems was terribly exciting for a young graduate student. His book was thus a major reason that I chose the field of public finance - or, as Musgrave himself called it in the subtitle of his book, public economy - for the principal preoccupation of my career. It is a pleasure to participate in this event to express our appreciation to him on the occasion of his 90th birthday.

Among the most important of the ideas that we students encountered in The Theory of Public Finance was the conceptual division of the government's budget into Allocation, Distribution and Stabilization branches. It is to the consolidation of the subbudgets of 
these three branches, each informative about the function served, that Musgrave refers in the quotation at the head of this paper. In his preface (p. v), Musgrave begs the reader "not to discard this somewhat utopian scheme [of three informative subbudgets] with the sterile objection of 'utterly impracticable.' Let its practicability be tested not by the prospects for speedy enactment but by the contribution it has to make to orderly thinking about the basic issues of budget policy." In this paper I revisit, in the light of developments in economics since Musgrave wrote, the question whether budgetary practices could be made more directly informative about two of Musgrave's conceptual functions of government. Reflecting my inadequacies as a macroeconomist, I restrict my attention to the allocative and distributional branches.

My subject is the budget as a way of describing what the government does, monitoring its performance, and planning for its future. My easy thesis is that there is a serious problem of meaning in the terms we use - such as taxes, spending, deficits -- what I call the "budgetary language." My harder thesis is that it is within our reach to improve the situation significantly. The general ideas that I present May seem obvious to professional readers. But not very many people outside the profession seem to understand them, or, perhaps better said, a great many people clearly do not understand them. And even trained economists oft go astray.

Given the stakes involved, and the complexity of the material, it is not surprising that we find in budgetary debates a great deal of "smoke and mirrors." Our present budgetary concepts invite such manipulation because they are not economically well defined. It is always difficult to tell whether people are able to see through accounting 
data to underlying realities. A good example from the private sphere would be the treatment of retirement pensions (see Beaver and Landsmann, 1983). Under early standards, companies with very different obligations could have identical balance sheets. Changes in the rules to make information about pension obligations explicit in financial accounts were the subject of bitter controversy. On the other hand, it is possible that the valuation placed on a company by financial experts was already independent of these accounting data. Such experts could ferret out the company's real situation, using information supplemental to standard financial accounts.

Experience suggests to me, however, that misunderstanding of the economic reality behind government budgetary information seriously influences policy. While I would not advocate or expect immediate replacement of present rules with economically meaningful alternative conventions, I do believe there is a case for fairly radical overhaul of our budgetary language. At a minimum, supplementary accounting information, based on economically meaningful conventions, could go a long way toward achieving improved transparency about what is going on and more effective planning for the future.

In this paper I propose as the building blocks of such a language the elements of the standard description of the household's economic circumstances: the level of its budget constraint, the prices it faces, and the economic environment (read levels of public goods) in which it finds itself. Before getting to this image of the road to reform, I illustrate the need for it with four examples of problems with existing budgetary language in the United States. If some of these examples seem a bit dated it is because I used them some time ago in teaching public finance. No doubt, I could bring them up to date but, unlike 
undergraduates, the present readership does not need the excitement provided by connection with today's New York Times. I am sure the problems I describe persist today, at least in the United States. In that regard, I must apologize for the parochial attachment to the U.S. budgetary institutions that I know reasonably well. A referee has suggested that substantial transparency has been achieved in Australia, New Zealand and the United Kingdom. Regrettably, I have not been able to determine the extent to which these countries have solved the puzzles posed here. Reliance in Europe on criteria such as the Maastricht standards for budgetary discipline, which are subject to the criticisms raised below, suggests to me that there is plenty of room for improvement in the practices of other countries.

\section{FOUR EXAMPLES}

Example 1. Are They Spending Cuts or. Tax Increases?

The first parable is drawn from debate I observed as an interested participant in discussion of fiscal plans that emerged as William Clinton moved from U.S. Presidentelect to President. Conservatives voters had deserted President George Bush after he violated his pledge for "no new taxes." Reflecting the same political mood, candidate Clinton campaigned as a New Democrat on a theme of cutting deficits by controlling spending, rather than raising taxes.

At Senate hearings for his confirmation, Clinton's nominee for Director of the Office of Management and Budget, Leon Panetta, asserted his aim to achieve deficit reduction by cutting spending and raising taxes, with three dollars of spending cuts for 
each dollar of tax increases. Later, as December turned to January, Mr. Panetta suggested it might be possible to achieve two dollars of spending cuts for each dollar of tax increases. Shortly before the President's economic message late in the month, his spokesman hinted on a Sunday talk show that the President was aiming for "balance" in his budgetary proposals. In the event, President Clinton announced in his speech his intention to implement \$247 billion in spending cuts over a five-year period, together with, surprise, $\$ 246$ billion in tax increases.

In the subsequent debate, critics redid the numbers in many ways. In a typical example, the Senate Budget Committee minority (Republican) staff concluded that the version of the Clinton program that passed the House incorporated $\$ 6.35$ in taxes for each $\$ 1$ in spending cuts. The argument involved in part matters of defining baselines and of netting. My interest here, however, concerns the debate over what is a tax increase and what is a spending cut. An excellent example was the Clinton Administration's proposal to increase the portion of Social Security retirement benefits that are subject to income taxation (a proposal that was subsequently enacted). The Administration described this proposal as a reduction in spending of $\$ 21.4$ billion over five years. It did not count the change in its table of "revenue provisions," where tax changes are customarily summarized. Critics cried foul and they found support in the analysis by the even-handed Congressional Budget Office that placed the provision in the category of "revenue proposals."

What is the nonpartisan truth here? Was the Social Security proposal a spending cut or a tax increase? Economics tells us that the label is uninformative. It is a 
commonplace of public finance that transfer payments (such as Social Security retirement benefits, commonly classified as expenditures) and taxes (such as income taxes) are entirely symmetric. Thus, in The Theory of Public Finance (p. 272), Musgrave notes, "In a formal sense, transfers may again be looked upon as negative taxes." But to do so is not normal practice in budgetary debate. Interestingly, it is also still not the standard approach taken in courses in public finance. On the same page of The Theory of Public Finance, Musgrave observes in connection with transfer payments that "consumer behavior may be affected from the expenditure as well as from the tax side of the budget," thereby implicitly accepting a useful distinction, as have his textbook successors.

We have here a problem due to aggregation along the lines Musgrave pointed out in the quotation at the head of this paper. Sometimes there is a real difference to be concerned about. But in the circumstances that spending and taxes are really the same thing, the classification shouldn't matter, should it?

Example 2. A Balanced Budget Policy Change May Be Hard on Future Generations

The present distinction between taxes and spending is based on institutional convention, not economics. One might say so much the worse for economics, were it not for the evident problems occasioned by mistaken reliance on the tax/spending distinction. Nowhere is this clearer than in present budgetary politics in the United States. The first example worked mainly off the equivalence of taxes and transfers. The second example is closely related, in that it involves, in effect, taxes and transfers as they affect different generations of citizens. At time of writing, politicians in the United States are debating the 
best use of large budget surpluses; not long ago, they were struggling to overcome budget deficits. Arguably, in the recent past they were understating the fundamental intergenerational distributional problem. By the same token, today they are probably overly optimistic about the future, in the sense that they would behave differently if they had better budgetary language.

We can easily illustrate the problem with present conventions with the case of an extension of some benefit flowing to older residents, for example, an improvement in the prescription drug provisions under Medicare (the health insurance provided to the elderly). If such an improvement were financed by an increase in the payroll tax, there would be a net transfer to existing elderly residents at the expense of younger residents, including the as yet unborn. Alternatively, finance through, say, an increase in the premiums paid by the current elderly would leave unchanged the anticipated net tax on currently young and future cohorts. Both of these programs would, however, have the same impact on the budget deficit, current and projected. Does the budget deficit matter?

\section{Example 3. Tax Expenditures and Their Opposites (Taxes?)}

The third example involves real expenditures. It may seem a bit quaint, as it comes from those days when we worried about how to cut the deficit, not how to spend the surplus, but the generic point is no less apt today. The example features the secret Bradford plan to balance the budget without raising taxes and without reducing defense capability (or any other real spending program)

Step 1 of the Bradford plan is to cut the weapons procurement request in the defense budget to zero. Taken by itself, this would harm defense capacity. Step 2, 
designed to offset this unfortunate effect, calls for enactment of a new "weapons supply tax credit" (WSTC). To qualify for the WSTC, manufacturers will sign appropriate documents prescribed by the Secretary of Defense (looking much like today's procurement contracts) and deliver to appropriate depots weapons systems of prescribed characteristics. The WSTC, which may be transferred to other taxpayers without limit, may only be used in payment of income tax. Step 2 is, apparently obviously, a tax cut.

A time of concern about budget deficits is patently not a time for a tax cut, so Step 3 is a revenue-neutral tax reform, under which the new tax credits are offset by including all Social Security Benefits in taxable income and eliminating the mortgage interest deduction.

Steps 1 and 2 would have a large effect on the budgetary totals, resulting in a large cut in spending and an equal cut in taxes. But the economic reality would be unaffected until Step 3, which would more or less radically change the distributive impact of the fiscal system under the cover of revenue neutral reform.

It is true that the chances are pretty good some astute politician or journalist would notice what is going on in this case. Maybe the policy process would see through to the economic substance. But maybe not; permit me to doubt. In any case, I believe the implied description of present budgetary language is completely accurate.

Example 4. How to Spend (and Tax) Without Spending (or Taxing): Mandates. The fourth situation calling for better economic description is the use of regulation to influence the allocation of resources and distribution of income. Consider a mandate that employers provide health insurance for their workers as an approach to health care 
reform. Such a scheme would have rather complex incidence but, except for the unlikely case that the mandate matches what people would do on their own, we know there will be gainers and losers and there would be allocative effects from its introduction, just as there would be for a program of taxes and subsidies, or a program of public provision of health insurance that would generate the same result. Yet (neglecting such features as the deductibility of the employers' outlays under the income tax) the mandated system would have no direct budgetary consequences. (Bradford and Max, 1997, quantify the taxes and transfers implicit in an illustrative mandate for the United States.)

Or consider, for example, the requirement under U.S. law that makes potentially responsible parties, ("prp's") defined very broadly, jointly and severally liable for cleaning up abandoned hazardous wastes. Here, a large program of expenditure is being financed by an implicit tax on the prp's.

Environmental regulation is increasingly important in most advanced economies and while it may well be worth it, it is often expensive. For example, the U.S. government estimated that just one law, the Clean Air Act Amendment (an amendment to the already existing rules) passed in 1990 would, when fully phased in, impose roughly $\$ 25$ billion per year in compliance costs. Other examples of regulations: Requirements that local governments assure that waste water released into waterways be up to national drinking standards, or that governments and businesses provide handicapped access to all public facilities.

With a little imagination, one can generally construct a program of taxes and expenditures, as the terms are conventionally understood, that will exactly duplicate the 
effect of regulatory programs such as these. The duplicating provisions would be reflected in conventional budgets. Yet the regulatory programs do not show up there. What should our objective be in approaching the measurement of such regulatory programs?

\section{TOWARD IMPROVEMENT IN BUDGETARY LANGUAGE}

Budget information concerns how the world looks (or would look, in the case of proposed budget plans) compared to some hypothetical status quo ante. In general, the implicit status quo ante is the absence of government. To be sure, the actual numerical figures are probably best thought of as some sort of approximation to such a description. For example, when we say that the United States is spending $\$ 300$ billion on national defense we must mean something like that if we eliminated all those programs, there would be $\$ 300$ billion of other goods and services available in the economy. We know we cannot take such a figure literally. Matters such as the speed with which such a huge hypothetical policy change might be effected would radically influence the actual impact. But the figure still is presumably to be interpreted as a measure of difference from the conterfactual baseline "null" policy of no expenditures on national defense.

As Musgrave pointed out in his discussion of budget items in the social accounts

(The Theory of Public Finance, pp. 184-85), most of the use of aggregates such as the level of defense expenditures is to assess year-to-year changes. To interpret the effect of an increase in defense outlays from $\$ 300$ billion to $\$ 320$ billion as the value of alternative goods and services foregone is likely to make reasonable sense. 
The strategy that I suggest is to base accounting conventions on the building blocks of budget constraints and prices. We know, in principle, how to describe people's economic situations in ways that are quite independent of fiscal institutions. With due regard for the level of abstraction involved, we may say that the economic situation of an individual is described by budget constraints, intra- and intertemporal, together with environmental variables, including government-provided services. Putting it loosely, we can describe the economic reality by the amount of money people have to spend, the prices they face, and the amounts of public goods available to them. This can be done in ways that are independent of the many possible institutional arrangements that could give rise to the same set of economic circumstances of individuals.

The same tools should permit us to describe alternative policies unambiguously. The real content of defense "spending" is a measure of the quantity of troops and tanks, whether paid for by check or by tax credit. The real effect of an investment subsidy is to change a certain price facing producers, whether the subsidy is implemented by a Commerce Department program or by accelerated depreciation in an income tax. The real effects of an income tax and an income-related phase-out of welfare benefits are the same, and would be identically described in a system of real fiscal accounts.

The ideal set of budget accounts should show how much we are spending and what we are spending it on, and it should be more refined about who the "we" is than a single aggregate "we." It should show the amounts subsets of us are gaining and other subsets are losing, including importantly an identification of gains and losses by generational cohorts. 
Finally, the budget should show impacts of programs implemented through mandates/regulation.

\section{$\underline{\text { Budgetary Language In SOME SimPle MOdel ECONOMIES }}$}

In the Musgrave tradition, we might ask how the problem would look in a simple model economy, consisting of two people, let us call them A and B.

$\underline{\text { Taxes and Transfers: Intratemporal }}$

To capture the basic distributive problem, consider a world with just one private good, call it $\mathrm{X}$, in addition to labor. Each person $i$ acquires a quantity $x_{i}$ of $\mathrm{X}$ by working $l_{i}$ units of time subject to a budget constraint determined by his (pardon the gender convention) productivity (assumed equal to his wage), $w_{i}$, less a lump sum tax paid to the government, $T a_{i}$, plus a lump sum transfer received from the government, $T r_{i}$ :

$$
\begin{gathered}
x_{A}=w_{A} l_{A}-T a_{A}+T r_{A} \\
x_{B}=w_{B} l_{B}-T a_{B}+T r_{B} \\
T a_{A}+T a_{B}=T r_{A}+T r_{B},
\end{gathered}
$$

where the third equation expresses the government's budget constraint.

Note that the aggregates of taxes and transfers are uninformative about the distributive properties of the budget. They could both be large but each person's tax could exactly equal his transfer. To describe the government's program in this economy, it suffices to record the net tax paid or net transfer received by each of the two citizens; let us call the net tax $\operatorname{Tan}_{i}$. Then all we need to know about the government's policy is captured 
unambiguously by the pair, $\left(\operatorname{Tan}_{A}, \operatorname{Tan}_{B}\right)$. (A detail: Because of the government's budget constraint, we only need to specify $n-1$ one of these, where $n$ is the number of people. When, as in the example, there are just two people, this makes a big difference. In the more general case, with large $n$, the government's budget constraint will provide very little information.)

\section{$\underline{\text { Taxes and Transfers: Intertemporal }}$}

Bringing in time poses serious challenges to meaningful budgetary language. To isolate the key issues, consider a two-period world. Now we need to add period superscripts, 1 or 2 , to everything in sight. The following system describes the budget constraints as of period 1 in terms of the basic economic system plus net taxes.

$$
\begin{gathered}
x_{i}^{1}+\delta x_{i}^{2}=w_{i}\left(l_{i}^{1}+\delta l_{i}^{2}\right)-\left(\operatorname{Tan}_{i}^{1}+\delta \operatorname{Tan}_{i}^{2}\right), \quad i=A, B \\
\operatorname{Tan}_{A}^{1}+\operatorname{Tan}_{B}^{1}+\delta\left(\operatorname{Tan}_{A}^{2}+\operatorname{Tan}_{B}^{2}\right)=0,
\end{gathered}
$$

where the wage rates are presumed the same in both periods and where $\delta$ is the discount factor in the model economy.

In this depiction, I have taken for granted that the budgetary information will have dealt with the netting of taxes and transfers. Specification of the net transfers in period 1 is, however, uninformative about the impact of the fiscal plan on the two people in the

economy. Thus, we could give everyone a "tax cut" in period 1, so that both $\operatorname{Tan}_{A}^{1}$ and $\operatorname{Tan}_{B}^{1}$ are negative. This would be accord with usage in policy debates in the United States today. The government's budget constraint tells us, however, that this is, at best, an incomplete description of policy. 
In the intertemporal framework, one needs to specify the full set of net taxes through time, or, sufficiently, their discounted value, to capture the distributive impact of the budget. Here that would mean specifying the discounted net transfers to each taxpayer (or class of taxpayers), $\operatorname{Tan}_{A}^{1}+\delta \operatorname{Tan}_{A}^{2}$ and $\operatorname{Tan}_{B}^{1}+\delta \operatorname{Tan}_{B}^{2}$. (In this case, the government's budget constraint makes one of the two redundant but, as before, this is an artifact of the two-person example.)

In a real world setting, with an indefinite horizon, policy is never projected through through time in a way consistent with the government's intertemporal budget constraint. More practically, one could hope to specify some sort of current projection of the future net taxes, say in the form $\operatorname{Tan}_{A}^{1}+\delta \operatorname{Tan}_{A}^{2, p r o j e c t e d}$ and $\operatorname{Tan}_{B}^{1}+\delta \operatorname{Tan}_{B}^{2, p r o j e c t e d}$. Some summary of the unresolved intertemporal budget requirement would be needed to complete the budgetary description. In our simple economy, it could be a statement of the net tax in the aggregate that remains to be assigned to the two people in the next period, $\operatorname{Tan}_{\text {aggregate }}^{2, \text { residal }}$. Using the intertemporal budget constraint this quantity is related to the known and projected net taxes by

$$
\operatorname{Tan}_{\text {aggregate }}^{2, \text { residual }}=-\frac{\operatorname{Tan}_{A}^{1}+\operatorname{Tan}_{B}^{1}+\delta\left(\operatorname{Tan}_{A}^{2, \text { projected }}+\operatorname{Tan}_{B}^{2, \text { projected }}\right)}{\delta} .
$$

The idea generalizes to the setting of an indefinite horizon, except that some way is needed to normalize to express the net tax residual on an annual basis. For example, one could ask what uniform annual aggregate net tax, starting next period, 
$\operatorname{Tan}_{\text {aggregate }}^{\text {starting } 2 \text { residual }}$, would be sufficient to satisfy the intertemporal budget constraint. This quantity would be related to the projected net taxes by

$$
\operatorname{Tan}_{\text {aggregate }}^{\text {startingin } 2 \text { residual }}=-r \sum_{0}^{\infty} \delta^{j}\left(\operatorname{Tan}_{A}^{j+1, \text { projected }}+\operatorname{Tan}_{B}^{j+1, \text { projected }}\right),
$$

where $r$ is the discount rate implicit in the discount factor, $\delta$. Alternatively, and perhaps more helpfully, one could express the undetermined residual as the constant per capita amount, or as the constant fraction of some measure of per capita income, that would do the job.

\section{$\underline{\text { Public Goods }}$}

Returning to the single-period context, let us add a public good, G. Assume it is measured in units of its cost in the private good foregone to produce it; in these units the production possibility frontier of $\mathrm{G}$ and $\mathrm{X}$, given labor inputs, is linear with slope -1 . The budget constraints of the two citizens would be the same as in the previous case, but the outcome that they would value would now be expressed in terms of a quantity of the private good and the level of provision, $g$, of the public good. The government's budget constraint would become

$$
T a_{A}+T a_{B}=T r_{A}+T r_{B}+g
$$

Now to describe the impact of the government on the two citizens we need the three items, $\left(\operatorname{Tan}_{A}, \operatorname{Tan}_{B}, g\right)$. In other words, we need to add to the net (private good) distributive impacts of the budget the amount of the public good provided. 
One might, in addition, be interested in the valuation placed on the public good. Public good provision would be the province of the Allocation Branch in Musgrave's scheme. He conceived of the Allocation Branch as assessing the amount citizens would be willing to pay for the public good. In his illustrative analysis, in my notation, the Allocation Branch sets a tax on the citizen $i$ of $T a_{i}^{a}$, where it is assumed that the benefit provided to $i$ (measured by willingness to pay in terms of the private good) is at least as great as $T a_{i}^{a}$. These taxes would be set to balance the Allocation Branch budget:

$$
T a_{A}^{a}+T a_{A}^{a}=g .
$$

A perhaps minor matter: The surplus generated by optimizing choice of $g$ drops out of this account. (Also omitted are the shortfalls that might be generated for one or another citizen if the level of the public good is inefficient or if the willingness to pay is misestimated in setting the Allocation Branch taxes.)

We would then need to put a Distribution Branch superscript on the net taxes charged by that branch, and they would always satisfy

$$
\operatorname{Tan}_{A}^{d}+\operatorname{Tan}_{A}^{d}=0 .
$$

By construction, the distribution branch net taxes would capture the idea of "true" redistribution of the consumption equivalent generated by the economy.

Musgrave's ideal Allocation Branch taxes raise an interesting philosophical issue about the purpose of budgetary data. One might argue that the objective of the budgetary figures is to give us "the facts" about the policies of the government, leaving it to further, and more controversial, analyses to decide on the valuation of what government does or 
proposes. By contrast, Musgrave's Allocation Branch's further step of estimating the value placed on public goods requires a higher order of analysis that is, indeed, "utopian," relative to today's practice, which, at best, stops at an accounting for the level, $g$, of the public good provided.

\section{Distorting Commodity Taxes and Subsidies}

A further set of issues arises when we have more than one private good, with the possibility of taxes and subsidies applied to them. Let the second good be Y. To simplify, let us maintain the linearity of the production possibility frontier and choose the units of $Y$ so that the marginal rate of transformation between $\mathrm{X}$ and $\mathrm{Y}$ is always 1 . Let the rate of tax on purchases of commodity $j$ be $t_{j}$ and the rate of subsidy be $s_{j}$. With these new policy instruments (and abandoning the separate Allocation and Distribution Branch distinctions), the three budget constraints of our little one-period economy become

$$
\begin{gathered}
\left(1+t_{x}-s_{x}\right) x_{A}+\left(1+t_{y}-s_{x}\right) y_{A}=w_{A} l_{A}-\operatorname{Tan}_{A} \\
\left(1+t_{x}-s_{x}\right) x_{B}+\left(1+t_{y}-s_{x}\right) y_{B}=w_{B} l_{B}-\operatorname{Tan}_{B} \\
\operatorname{Tan}_{A}+\operatorname{Tan}_{B}+t_{x}\left(x_{A}+x_{B}\right)+t_{y}\left(y_{A}+y_{B}\right)=s_{x}\left(x_{A}+x_{B}\right)+s_{y}\left(y_{A}+y_{B}\right)+g,
\end{gathered}
$$

where the previously defined tax and transfer terms refer now just to the lump sum components of the government's program

An obvious point to make about this system is that it is redundant in policy instruments. Present budgetary language would, however, attach significance to the separate pieces. The bits labeled "subsidies" would be identified as expenditures, characterized not by the rates but rather by the product of rates and quantities. So the 
expenditure on the subsidy to good $\mathrm{X}$ would be recorded as $s_{x}\left(x_{A}+x_{B}\right)$, and the subsidy to $\mathrm{Y}$ as $s_{y}\left(y_{A}+y_{B}\right)$.

It seems that the distinction between a subsidy and a tax in the conventional sense is a matter of intent. A subsidy in the conventional sense is "on purpose" and a tax in the conventional sense (apart from a Pigouvian offset to an externality) is an unfortunate necessity. It is unclear, however, whether one can construct a satisfactory accounting distinction based on intent. If consumers and producers are looking only at real tradeoffs, rather than labels, the economically significant quantities are the net tax (or subsidy) rates. If we normalize on earnings and denote the net tax on good X by $t n_{x}$, etc., the system of budget constraints becomes

$$
\begin{gathered}
\left(1+t n_{x}\right) x_{A}+\left(1+t n_{y}\right) y_{A}=w_{A} l_{A}-\operatorname{Tan}_{A} \\
\left(1+t n_{x}\right) x_{B}+\left(1+t n_{y}\right) y_{B}=w_{B} l_{B}-\operatorname{Tan}_{B} \\
\operatorname{Tan}_{A}+\operatorname{Tan}_{B}+t n_{x}\left(x_{A}+x_{B}\right)+\operatorname{tn}_{y}\left(y_{A}+y_{B}\right)=g .
\end{gathered}
$$

The key budgetary information, expressed in revenue terms, would be the net tax revenue totals, $\operatorname{tn}_{x}\left(x_{A}+x_{B}\right)$ and $t n_{y}\left(y_{A}+y_{B}\right)$. Typically, such net tax revenue quantities would include both positive and negative (i.e., net subsidy) values. Note that this accounting would neglect the deadweight loss that might be due to the distorting taxes. Including estimates of these distortionary effects raises the same philosophical and analytical issues as does including estimates of the valuation of public goods. 
Even with normalization on earnings along the lines described (so there is no tax or subsidy on working), there remains a question how to summarize the impact of the government budget when there are many commodities. How does one summarize the set of effective taxes that come between the producer prices (unity, by choice of units) and the prices facing the consumer/worker? I have not tried to identify an answer, but perhaps one could choose some reasonable aggregates of goods and services (say, food, housing, transportation, all others) and use an aggregation of their before- and after-tax/subsidy prices derived from the index number literature.

Some thought needs to be given to how one best characterizes the distributive impact of net commodity taxes on individuals. In the illustrative case, if there were no lump-sum taxes, we would have no obvious distributive information. The budget situation of the individual would nonetheless be changed by the policy compared to the situation of no net taxes and no public good provision. The impact of the policy on each individual would be captured, from a formal perspective, by the statement that the net price of $\mathrm{X}$ is increased by $t n_{x}$, the net price of Y by $t n_{y}$, and the level of public good by $g$. All three of the measures have, in this case, the quality of public goods. But this is too much information. A useful budgetary convention would be based on a measure of the incidence of the policy package, a measure I have not tried to derive here. 


\section{Taxes on Earnings}

The big enchilada of distorting taxes is the one on labor supply. Suppose only a labor income tax and lump-sum taxes are used, and that the labor income tax rate applied to person $i$ is $\tau_{i}$. Then, for the single-commodity case, our budget constraints become

$$
\begin{gathered}
x_{i}=\left(1-\tau_{i}\right) w_{i} l_{i}-\operatorname{Tan}_{i}, \quad i=A, B \\
\operatorname{Tan}_{A}+\tau_{A} w_{A} l_{A}+\operatorname{Tan}_{B}+\tau_{B} w_{B} l_{B}=g .
\end{gathered}
$$

Present practice in this case would be to define the net tax on citizen $i$ as $\tau w_{i} l_{i}+T a_{i}$. This gets the story wrong, in the first place by failing to net taxes and transfers, to make it $\tau w_{i} l_{i}+\operatorname{Tan}_{i}$. Further, the "proper" sign convention would call for treating the tax on labor as a negative net tax (subsidy) on nonmarket time that we conventionally call leisure. Consistency with the suggested description of commodity taxes and subsidies would suggest describing the budget in terms of the net lump-sum tax elements plus the leisure subsidies. (Also, although not, strictly speaking, an element of budgetary aggregates, the common characterization assigns an incidence to one transaction tax instrument, the tax on labor, that neglects proper treatment of leisure foregone as well as general equilibrium effects.)

An approach that I find intriguing is a normalizing convention such that all distorting taxes are expressed as what we conventionally call commodity taxes. This would capture the idea of a fundamental tradeoff between work and various desired goods. So, a $10 \%$ tax on earnings would be expressed, instead, as a uniform $11 \%$ (i.e., $1 /(1-.1) \%$ tax on goods. Where the earnings tax rate varies from worker to worker, such net taxes on 
goods would be person-specific, an awkward but accurate description of economic substance. Note, however, that the approach would require identifying, not simply earnings in general, but earnings at a specific time, e.g., the present, if this idea were extended to an income tax context. In that setting, there would typically be a different rate of tax on the same good at different distances into the future. Thus the rate of tax on a standard consumption good at successive dates in the future, expressed in terms of current earnings, would be higher and higher, reflecting the penalty on saving imposed by an income tax. Such a way of describing the budget's impact might affect people's attitudes toward an income tax.

Alternatively, one could normalize on some standard private good. To illustrate, consider A's budget constraint with an earnings tax and a pair of net commodity taxes, as discussed above:

$$
\left(1+t n_{x}\right) x_{A}+\left(1+t n_{y}\right) y_{A}=\left(1-\tau_{A}\right) w_{A} l_{A}-\operatorname{Tan}_{A} .
$$

Suppose we were to take good $\mathrm{X}$ as numeraire. Then the normalized budget constraint would be

$$
x_{A}+\frac{\left(1+t n_{y}\right)}{\left(1+t n_{x}\right)} y_{A}=\frac{\left(1-\tau_{A}\right)}{\left(1+t n_{x}\right)} w_{A} l_{A}-\frac{\operatorname{Tan}_{A}}{\left(1+t n_{x}\right)} .
$$

The normalization would need to be carried through all of the budget constraints, including the government's. Let me describe the resulting net tax rates, etc., by putting a superscript on them, so the new budget constraint looks like

$$
x_{A}+\left(1+n_{y}^{x}\right) y_{A}=\left(1-\tau_{A}^{x}\right) w_{A} l_{A}-\operatorname{Tan}_{A}^{x},
$$


where

$$
\begin{aligned}
t n_{y}^{x} & \equiv \frac{\left(1+t n_{y}\right)}{\left(1+t n_{x}\right)}-1 \\
\tau_{A}^{x} & \equiv 1+\frac{\left(1-\tau_{A}\right)}{\left(1+t n_{x}\right)} \\
\operatorname{Tan}_{A}^{x} & \equiv \frac{\operatorname{Tan}_{A}}{\left(1+t n_{x}\right)}
\end{aligned}
$$

A normalization of this kind can reveal some surprises. To put some illustrative numbers on the story, suppose taxpayer $\mathrm{A}$ is paying a $25 \%$ tax on earnings and getting a $\$ 1000$ net transfer; there is a $20 \%$ tax on commodity $\mathrm{X}$ and a $10 \%$ tax on commodity $\mathrm{Y}$. Such magnitudes might well be encountered in a system with a VAT and an income or a payroll tax. With the suggested normalization, we would say that taxpayer A faces an earnings tax of $62.5 \%$ (reflecting the impact of the system on his ability to trade working for the numeraire good, $\mathrm{X}$ ), gets a net transfer of 833 units of $\mathrm{X}$, with a subsidy of his purchases of $\mathrm{Y}$ at rate of $81 / 3 \%$.

Of course, the choice of numeraire good is arbitrary. More plausible than a single commodity, a standard bundle of consumer goods - purchasing power - would be a more natural choice in a real application. Thus if, in this example, we had chosen to normalize the net of commodity tax prices of the goods base on some bundle of $\mathrm{X}$ and $\mathrm{Y}$, instead of on $\mathrm{X}$ alone, the story would imply some small (less than the $20 \%$ nominal rate) net tax on $\mathrm{X}$ and a smaller than $81 / 3 \%$ net subsidy of purchases of $\mathrm{Y}$.

Before leaving this set of issues, I might add yet one more complicating factor: If the linearity assumption about the production system is invalid, specifying for each person 
the applicable rate of earnings tax, the appropriate net commodity taxes, and the lump sum tax (together with the level of public goods provided) is, in principle, no longer sufficient to determine the impact of the government's program on that person. That is because the program overall will generally affect wage rates, quite possibly the most important way a program affects a person. Franklin Allen (1982) provides a striking example in which "standard" views about the progressivity of a tax are overturned by general equilibrium effects on skill-related wages.

\section{$\underline{\text { Tax Expenditures }}$}

Finally, this setup of the problem may yield some insight into the problem of tax expenditures. Returning to the two-commodity example, take the case in which the taxes and subsidies on $\mathrm{X}$ are zero (or where we have normalized on commodity $\mathrm{X}$ ), but a deduction is allowed from the earnings tax base for the purchase of Y. Then the budget constraints become

$$
\begin{aligned}
& x_{A}+\left(1+t_{y}-s_{y}\right) y_{A}=\left(1-\tau_{A}\right)\left(w_{A} l_{A}-\left(1+t_{y}-s_{y}\right) y_{A}\right)-T a_{A}+\operatorname{Tr}_{A} \\
& x_{B}+\left(1+t_{y}-s_{y}\right) y_{B}=\left(1-\tau_{B}\right)\left(w_{B} l_{B}-\left(1+t_{y}-s_{y}\right) y_{B}\right)-T a_{B}+T r_{B},
\end{aligned}
$$

where I have neglected the government's budget constraint in the interest of reducing the clutter. These budget constraints can be reduced to a "canonical" form (prices times quantities of goods on the left; after-tax wage times labor supply plus lump sum transfer on the right) by some algebra. I reproduce here A's budget constraint:

$$
x_{A}+\left(1+t_{y}-s_{y}+\left(1-\tau_{A}\right)\left(1+t_{y}-s_{y}\right)\right) y_{A}=\left(1-\tau_{A}\right) w_{A} l_{A}-\operatorname{Tan}_{A} \text {. }
$$


One way to describe this constraint is to say it involves a net tax, $t n_{y, i}$ on $\mathrm{Y}$, specific to person $i$, that is defined by (for the case of person A)

$$
t n_{y, A} \equiv 1+t_{y}-s_{y}+\left(1-\tau_{A}\right)\left(1+t_{y}-s_{y}\right)-1 .
$$

If we wanted to describe the resulting government program as "spending" on $\mathrm{Y}$ (for example, as a subsidy program for housing) we could multiply up the implicit subsidy rates and quantities, to obtain a total:

$$
t n_{y, A} y_{A}+t n_{y, B} y_{B} .
$$

I would not claim it is beautiful but it is unambigous.

\section{APPLICATION TO THE FOUR EXAMPLES}

Having in mind the ideas developed somewhat formally for our little model economy we may consider whether there is any practical progress to be made on the four illustrative problem cases.

\section{Tax and Expenditure Sides of the Budget}

With respect to the example of the alternative views of including more social security benefits in the base of the income tax, the basic point is that it should not make the slightest difference whether something is called a tax increase or an expenditure cut, and therefore it should not affect our view of the policy, whether we like it or not. We should be looking for a language that describes the underlying reality. Note it is not just that present conventions are arbitrary, the way a foot or a meter is an arbitrary unit of length. As these cases clearly indicate, an arbitrary standard could have plenty of meaning. It is 
that present conventions are not grounded in economic reality, and therefore cannot suffice to describe it.

It seems to me an approach worth exploring would be to reserve the term "spending" or "expenditures" for something like government purchases of goods and services as inputs to the production of public goods. Assuming for the moment we can make such a distinction among outlays (for purposes of national income accounting, we already identify purchases of goods and services), it would seem to provide a useful normalization of the amount of public goods provided in the budget.

The term "taxes" might be used to refer to the net transfer of funds to the government in a year. Under this convention, the President would be obliged to say, "In my plan, I propose to change the income tax rules to increase the taxes on retirees by $\$ 21.4$ billion, to increase the taxes on higher income individuals by $\$ 120$ billion (or whatever it is), etc." If there is too much emotional freight attached to the term "taxes" one could, alternatively use language of net transfers from the government. Under this convention, the President would say, "In my plan, I propose to change the income tax rules to reduce the net transfers from the government to retirees by $\$ 21.4$ billion, to reduce the net transfer to higher income individuals by $\$ 120$ billion (or whatever it is), etc." It is true, this would take some getting used to. But, even if we did not insist on the President changing his rhetorical stripes, we could insist on the government keeping its books on such a basis.

Once we have expressed the government's accounts on a meaningful basis, it should be easier to focus the policy debate on the substance. The substance, in this case, is essentially distributive, and so it is most unlikely that aggregates (e.g., the statement that 
the net transfers increase by $\$ 60$ billion this year) are going to answer the questions that ought to interest people. We can see this clearly if we conceive of a government that engages only in redistribution. In that case, for every dollar paid in to the government in "taxes" there would be a dollar paid out in "transfers." The aggregate is algebraically zero. Further even if we distinguish the payments in from the payments out (as we probably should not, unless incentives are involved), the aggregate of either is of little consequence. In particular, it tells us little of interest about the size of government. What matters is the net gain or loss of one or another group in the society, and it is this that ought to be available to us, at various levels of detail, in the information on the budget.

As in the example of the President's speech, the interesting questions to be addressed with information about net transfers concern who gives and who receives, on net. We presume it does not matter to the retiree whether his social security benefit is cut by $\$ 200$ or his income tax is increased by $\$ 200$ (although maybe people do care about this). It seems to me there are likely to be many ways of disaggregating net transfers according to the characteristics of the people involved. Ability to pay or "income" of the payor/recipient is an obvious category of interest. This is the information addressed in a standard "distribution table," commonly used to describe income taxes. The perspective suggested here would involve relating a measure of net transfers to some measure of a person's pre-fiscal system opportunities or abilities, in contrast to the typical procedure followed today, in the United States at least, that counts explicit transfers, if at all, as part of the income "classifier." An ideal presentation would take a comprehensive approach, encompassing, for example, corporation income taxes, in-kind transfer programs, excise 
taxes, and state and local income and sales taxes. (Bradford, 1995, provides an overview of these procedures and a discussion of alternatives in the U.S. context.)

Age or generation is likely to be of interest as well, perhaps health status. A wellconstructed set of budget accounts should make it easy for policy makers and citizens to explore the impact of programs, and especially changes in programs, on various groups of concern.

This general approach would cry out for elaboration. For example, should one attempt to keep track of net transfers from government on the basis of an extended time, perhaps a person's lifetime? (Such issues would naturally arise in connection with the incidence of sharp transitions in policy, as, for example, in some versions of a transition from the present income tax to some versions of consumption tax.) In thinking about categories of affected individuals, what is the place for "special interest" groups, such as farmers or auto workers or tort lawyers?

I leave these questions for future speculation. But one assumption I have blithely made above deserves to be revisited, namely, the assumption that we can distinguish outlays that provide public goods, with the presumption that other outlays belong in the transfer category. For one thing, many outlays for goods and services are pretty clear substitutes for cash transfers to people: clinics providing health care to people of limited economic means would be an example. But government statisticians should be able to make reasonable calls about these. For another thing, some outlays have as their purpose advancing the economic interests of some constituency. A subsidy to domestic 
construction of merchant ships would be an example. It would add too much to the length of this paper to pursue these issues here.

\section{$\underline{\text { Budget Deficits }}$}

As it affects the budget sets of individuals, the problem of the government budget "deficit" is essentially one of distribution across generations. "Controlling the deficit" or "protecting the surplus" generally means, economically, shifting net fiscal burdens toward presently living (and perhaps especially the older among them) and away from future (and perhaps the younger among the presently living) generations. This viewpoint has been translated into practical accounting procedures in considerable detail in the "generational accounting" framework originated by Alan Auerbach, Laurence Kotlikoff and colleagues. (For an early exposition of the approach see Auerbach, Ghokale and Kotlikoff, 1990. Kotlikoff, 1992, provides an extended and entertaining treatment that documents the widespread confusion about the issues in the profession. Auerbach, Kotlikoff and Leibfritz, 1999, presents an application of generational accounting to the budgetary pictures of many countries around the world. Unfortunately, official generational account estimates for the United States were discontinued in 1994.)

The interests of different subgroups of the population would be expressed by a variety of "cuts" at the distribution of net transfers. The essential idea of generational accounts is to present the distribution according to birth cohorts. Auerbach et al have suggested various ways to characterize what I have called the "residual" net tax needed to comply with the intertemporal budget constraint. For example, one way is to calculate the hypothetical average uniform tax on earnings levied on all people with birth dates after the 
accounting year that would be required. Both generational accounting and this particular way of quantifying what Shaviro (1997) calls the "budget lag" are controversial and require a great many more or less speculative steps. On the other hand, they seem to me essential tools for fiscal planning.

\section{$\underline{\text { Tax Expenditures }}$}

How should we deal with the problem exemplified by my WSTC? Here we have the government acquiring some goods and services for purposes of providing a public good, national defense. The aggregate of such goods and services is, arguably, reasonably measured by the expenditure, and the expenditure is the same, whether it is the result of appropriating money and paying contractors in the usual way, or of providing a credit against income tax for people who supply the desired goods and services. It is therefore compelling that these two approaches to the problem of dealing with national defense should show up comparably in the budget.

The term "tax expenditures" was coined by then Assistant Secretary of the U.S. Treasury Stanley Surrey. (His viewpoint can be found in Surrey and McDaniel (1985); see also the discussion in Bradford (1986).) In his attempt to capture the equivalence between spending programs and features of the income tax law, Surrey conceived of tax expenditures as deviations from some sort of ideal or normal version of the tax. Application of the idea therefore requires identification of the normal or reference tax. Insofar as the reference tax has tended to be interpreted normatively, as what the system "should" be, it has naturally attracted controversy and reduced the appreciation of the analytically unassailable point of the exercise. 
My particular policy preference for consumption rather than Haig-Simons income taxation provides a case in point. The consumption-type treatment of retirement savings under the existing income tax is regarded by tax expenditure analysis as a subsidy to such savings. By contrast, if a consumption type tax is taken as the reference standard, the retirement savings provisions are "correct" and capital income taxes would be regarded as a negative subsidy (i.e., a tax!) on saving.

The missing element in this structure is the neutral status quo ante, corresponding to the zero expenditure on defense against which the defense outlay is measured. Unlike the conventional income tax baseline used in current tax expenditure accounting, there is no controversy about the baseline in the case of conventional expenditures. As our simple two-person economy suggests, it is conceptually possible to construct a measure of the expenditure programs implicit in our "tax" provisions that has the same normative neutrality as other budgetary information. The example also suggests a great deal of work is required to make that translation in a manner that can be understood in a policy context. In the meantime, we can take two messages from this discussion. First, it is essential to provide tax expenditure estimates. Second, the reference baseline used should be treated as analytically convenient, and not normative.

\section{$\underline{\text { Regulatory Taxing and Spending }}$}

A first principle ought to be that whatever measures we adopt recognize as equivalent policies that accomplish the same thing through "conventional" budgetary programs and through regulatory programs. In each of these cases, we could, with some ingenuity perhaps, construct a program of lump-sum grants and price subsidies that 
accomplish the same thing as the regulatory program. Programs should be recognizable as equivalent that translate into the same lump-sum grant plus price subsidies effects.

As an aside, the examples I cite differ in one interesting respect: the environmental regulation is producing a public good. The health care insurance regulation is producing a more complicated result, more like a requirement that people eat three times a day up to a certain standard.

It ought to be emphasized that regulatory programs can accomplish significant redistributive effect. Indeed, while there are some market failure arguments, it seems to me the distributive issues are often the dominant ones in the case of regulation. The nominal objective of obligatory health insurance, for example, is to redistribute from those with good health characteristics toward those with poor health characteristics, and typically even more important, from the relatively better off toward the relatively poor. In addition, transition effects may imply intergenerational impacts. (The implied redistribution from younger toward older cohorts in the population that would be effected by compulsory health insurance using age-independent "community rating" premiums is examined in Bradford and Max, 1997.)

The practical approach to recognizing the implicit taxing and spending in regulations is to push, to the extent possible, the careful translation of these programs into conventional taxing and spending programs and adding them to the budgetary information. This would be a substantial departure from present practices. 


\section{CONCLUSION}

Musgrave's conceptual division of the government's program into Allocation and Distribution Branch subbudgets retains its analytical power, even if the Stabilization Branch now may require a rather different treatment. The present paper has argued that progress towards Musgrave's ideal of a more informative budgetary language, one less or, ideally, not at all dependent on arbitrary institutional labeling, must be based on the nonarbitrary description of the individual's economic environment, as it is affected by government. As a first approximation, that environment can be summed up in terms of the individual's budget constraint and levels of public goods provided. Simple models suggest that an unambiguous budgetary language may be feasible but there remains much to clarify about both the objectives of the exercise and the specifics of methods to deal with particular problems. I conclude that significant improvement is possible, although both practical and conceptual problems present an interesting agenda for future research. 


\section{$\underline{\text { REFERENCES }}$}

Allen, Franklin, "Optimal Linear Income Taxation with General Equlibrium Effects on Wages," Journal of Public Economics, (XVII) 1982, pp. 135-143.

Auerbach, Alan J., Jagadeesh Gokhale, and Laurence J. Kotlikoff, "Generational Accounts: Meaningful Alternative to Deficit Accounting," Tax Policy and the Economy, (V), 1991, pp. 55-110.

Auerbach, Alan J., Laurence J. Kotlikoff and Willi Leibfritz, Generational Accounting Around the World, Chicago, IL: University of Chicago Press, 1999.

Beaver, William H., and Wayne Landsman, Incremental Information Content of Statement Thirty-Three Disclosures, Financial Accounting Standards Board, 1983

Bradford, David F., Untangling the Income Tax, Cambridge, MA: Harvard University Press, 1986.

Bradford, David F., ed., Distributional Analysis of Tax Policy, Washington, DC: AEI Press, 1995.

Bradford, David F., and Derrick A. Max, "Implicit Budget Deficits: The Case Of A Mandated Shift To Community-Rated Health Insurance," in James M. Poterba, ed., Tax Policy and the Economy, (XI) 1997, pp. 129-167 (revised version issued as Intergenerational Transfers Under Community Rating, Washington, DC: American Enterprise Institute, 1996.)

Financial Accounting Standards Board, "Objectives of Financial Reporting by Business Enterprises," FASB Satement of Financial Accounting Concepts No. 1, Stamford, CN: FASB, 1978. 
Kotlikoff, Laurence J., Generational Accounting: Knowing Who Pays, and When, for What We Spend, New York: The Free Press, 1992.

Musgrave, Richard A., The Theory of Public Finance: A Study in Public Economy, New York, NY: McGraw-Hill Book Company, Inc., 1959.

Shaviro, Daniel, Do Deficits Matter?, Chicago: University of Chicago Press, 1997.

Surrey, Stanley S. and Paul R. McDaniel, Tax Expenditures, Cambridge, MA: Harvard University Press, 1985. 